\title{
HUBUNGAN ANTARA KECERDASAN EMOSIONAL DAN PRESTASI AKADEMIK DENGAN JOB PERFORMANCE PADA MAHASISWA AKTIF ORGANISASI KEMAHASISWAAN
}

\author{
Talissa Carmelia ${ }^{1}$, Sri Tiatri ${ }^{2}$, Erik Wijaya ${ }^{3}$. \\ ${ }^{1}$ Jurusan Psikologi, Universitas Tarumanagara \\ Email: Carmelia693@gmail.com \\ 2 Jurusan Psikologi, Universitas Tarumanagara \\ Email: Sri.tiatri@untar.ac.id \\ 3 Jurusan Psikologi, Universitas Tarumanagara \\ Email: Erikfght@yahoo.com
}

\begin{abstract}
ABSTRAK
Kecerdasan emosional adalah kemampuan menerapkan daya dan kepekaan emosi. Prestasi akademik adalah hasil proses belajar. Job performance adalah penilaian dan evaluasi tugas. Belum ada penelitian mengenai hubungan antara kecerdasan emosi, prestasi akademik, dan job performance pada konteks organisasi kemahasiswaan di Indonesia sehingga tujuan penelitian adalah mengetahui hubungan ketiga variabel di organisasi kemahasiswaan. Penelitian ini melibatkan 284 mahasiswa yang terlibat di organisasi kemahasiswaan (DPM dan BEM). Hasil penelitian ini menunjukkan tiga temuan utama. Pertama, ada hubungan antara kecerdasan emosional dengan job performance ditinjau dari diri sendiri $(r=0,338, p=0,013)$ tetapi tidak ada hubungan ditinjau dari rekan kerja $(r=$ 0,080, $p=0,177)$, maupun dari ketua $(r=-0,108, p=0,069)$. Kedua, ada hubungan antara prestasi akademik dengan job performance ditinjau dari ketua organisasi kemahasiswaan $(r=0,147 ; p=0,00)$, tetapi tidak ada hubungan jika ditinjau dari diri sendiri $(r=-0,013, p=0,830)$, maupun rekan kerja $(r=0,056, p=0,352)$. Ketiga, tidak terdapat hubungan antara kecerdasan emosional dan prestasi akademik pada mahasiswa yang terlibat di organisasi kemahasiswaan $(r=-0,13, p=0,83)$.
\end{abstract}

Kata kunci: Kecerdasan emosional, prestasi akademik, job performance, organisasi

\section{PENDAHULUAN}

\section{Latar Belakang}

Secara umum, setiap universitas memiliki setidaknya satu organisasi kemahasiswaan sebagai sarana pengembangan potensi jati diri mahasiswa sebagai insan akademis, calon ilmuwan dan intelektual yang berguna di masa depan (Keputusan menteri dan kebudayaan, 1998). Organisasi kemahasiswaan secara umum terbagi beberapa, yaitu organisasi kemahasiswaan intra perguruan tinggi, organisasi kemahasiswaan antar perguruan tinggi, kegiatan kurikuler dan kegiatan ekstrakulikuler. Organisasi intra perguruan tinggi adalah wahana dan sarana pengembangan diri mahasiswa ke arah perluasan wawasan dan peningkatan kecendekiaan serta integritas kepribadian untuk mencapai tujuan pendidikan tinggi (Keputusan menteri dan kebudayaan, 1998).

Setiap universitas memiliki pembagian atau susunan organisasi yang berbeda, yang disesuaikan dengan kesepakatan antar mahasiswa, tidak bertentangan dengan peraturan perundangundangan yang berlaku, dan status, perguruan tinggi yang bersangkutan. Di Universitas Tarumanagara, memilki Ikatan Keluarga Besar Mahasiswa Tarumanagara (IKBMT, 2014) yang terdiri dari Majelis Permusyawaratan Mahasiswa (MPM), Dewan Perwakilan Mahasiswa (DPM), Badan Eksekutif Mahasiswa (BEM), Dewan Perwakilan Mahasiswa Fakultas (DPMF), Badan Eksekutif Mahasiswa (BEMF), Ikatan Mahasiswa (IMA) dan Unit Kegiatan Mahasiswa (UKM). Organisasi IKBMT ini secara struktural terdapat pada tingkat universitas, tingkat fakultas dan tingkat jurusan (IKBMT,2014). 
Organisasi kemahasiswaan ini dijalankan oleh para mahasiswa di perguruan tinggi tersebut. Para mahasiswa yang terlibat di dalam organisasi kemahasiswaan ini diseleksi dengan berbagai cara dan syarat yang telah ditentukan agar mahasiswa yang terpilih dapat mahasiswa yang berpotensi. Para mahasiswa yang dapat menjadi pondasi dalam menjalankan, mengembangkan dan mencapai job performance yang maksimal untuk organisasi kemahasiswaan ini. Job performance adalah sebuah dimensi yang mengindikasikan seberapa baik mereka mengerjakan tugasnya, seberapa inisiatif yang mereka miliki dan bagaimana usaha mereka dalam menyelesaikan masalah. Job performance juga dilihat dari bagaimana cara mereka menyelesaikan tugas, cara mereka memberikan tenaga, waktu dan kemampuan mereka dalam menyelesaikan masalah. Job performance dilihat dari beberapa tipe yaitu pertama, task performance yaitu seberapa baik para anggota dalam menyelesaikan tugas inti dan kewajiban yang telah diterima. Kedua, adaptive performance yaitu seberapa baik para anggota menyesuaikan diri dengan perubahan di dalam organisasi. Ketiga, contextual performance yaitu seberapa baik para anggota membantu di luar tugas inti yang dimiliki secara langsung atau tidak langsung (Pulakos et al, 2000; Rothmann \& Coetzer, 2003; Sonnentag dan Frese, 2002).

Job performance dilakukan sebagai bentuk penilaian dan evaluasi yang dilakukan setiap organisasi agar mampu memperbaiki kekurangan yang dimilikinya dan memperkuat kelebihan yang dimiliki. Job performance dipengaruhi oleh berbagai faktor seperti struktur organisasi, visi dan misi organisasi, sumber daya manusia, sistem organisasi (Tangkilisan, 2007). Peneliti melakukan komunikasi personal dengan ketua organisasi DPM dan BEM periode 2014-2015, mereka berpendapat bahwa anggota organisasi kemahasiswaan adalah faktor yang paling penting dalam mencapai job performance. Hal tersebut dikarenakan para anggotalah yang mempersiapkan dan menjalankan sebuah program kerja dari awal hingga akhir. Hasil yang diterima dari program kerja tersebut adalah usaha dan kerja keras para anggota. Kemudian, para ketua organisasi ini juga berpendapat bahwa memiliki IPK dan hubungan interpersonal yang baik di dalam organisasi kemahasiswaan sangat penting (Komunikasi personal, 5 April, 2015).

Para anggota yang berkualitas adalah individu yang mampu memiliki kecerdasan intelektual, kecerdasan emosional dan kecerdasan spiritual (Agustian, 2001). Kecerdasan intelektual dilihat dari prestasi akademik mahasiswa, dimana IPK adalah tingkat keberhasilan studi akademik yang dicapai oleh mahasiswa dari semua kegiatan akademik selama mengikuti proses perkuliahan. IPK dijadikan salah satu standar disebabkan sebagai salah satu penilaian hasil pendidikan, yang dilakukan mahasiswa selama proses perkuliahan, sejauh manakah hasil pendidikan anak didik setelah ia belajar dan berlatih dengan sengaja (Suryabrata,1998). IPK merupakan salah satu syarat pendaftaran anggota yang dimiliki oleh hampir seluruh organisasi kemahasiswaan, khususnya dewan perwakilan mahasiswa fakultas dan badan eksekutif mahasiswa fakultas.

Prestasi akademik merupakan sebuah tanggung jawab yang dimiliki seluruh mahasiswa. Pentingnya memperoleh prestasi akademik harus di usahakan dan dijadikan tujuan utama dalam berkuliah. Tidak bisa dipungkiri juga bahwa terlibat di dalam organisasi kemahasiswaan memiliki efek yang baik dan buruk untuk para mahasiswa. Hasil penelitian yang dilakukan oleh Yazidufalach (2014) menunjukkan bahwa terdapat keberhasilan di dalam perkuliahan yang dilihat melalui hasil Indeks Prestasi Kumulatif (IPK) yang sangat memuaskan disaat berorganisasi sehingga terlibat di organisasi kemahasiswaan dapat membantu meningkatkan indeks prestasi mahasiswa.

Hasil penyebaran kuesioner kepada 30 orang mahasiswa yang aktif di dalam organisasi kemahasiswaan DPM dan BEM pada tanggal 2 Februari 2015. Para mahasiswa berpendapat adanya kelebihan dan kekurangan dalam berorganisasi. Mereka berpendapat bahwa melalui 
berorganisasi dan mengikuti ekstrakuler, mahasiswa mampu mendapat pengalaman yang tidak bisa didapat dari pelajaran di kelas. Para mahasiswa mampu belajar mengenai leadership, manajemen waktu, komitmen, dan interaksi sosial antar angkatan. Para mahasiswa menjadi lebih percaya diri mengenai prestasi akademik yang dimiliki sejak terlibat pada organisasi kemahasiswaan, sehingga termotivasi untuk meningkatkan prestasi belajar.

Kekurangan yang dirasakan para mahasiswa adalah pertama, dalam pembagian waktu antara kuliah dan berorganisasi. Kedua, mempertahankan IPK mereka saat ini atau meningkatkannya. Para mahasiswa yang terlalu fokus dalam organisasi kemahasiswaan dapat menghambat proses perkuliahannya. Dari pengamatan peneliti sebagai ketua organisasi DPM Fakultas Psikologi periode 2014-2015, para anggota yang terlalu sibuk mempersiapkan program kerja yang sudah dekat, sangat mempengaruhi konsentrasi mereka selama berkuliah. Sebaliknya, di saat sudah mendekati ujian tengah semester atau ujian akhir semester, para mahasiswa mulai tidak bisa berkonsentrasi dengan program kerja yang akan berjalan. Walaupun begitu, peneliti melihat bahwa banyak diantara para anggota yang tetap memperoleh IPK yang sangat baik.

Penelitian yang dilakukan oleh Côté dan Miners (2006), menunjukkan bahwa kecerdasan emosional dan cognitive intelligence memiliki hubungan dengan task performance dan organizational citizen behavior (OCB) yang dilakukan di organisasi. Sedangkan hasil penelitian Goleman (1998), menyebutkan bahwa kecerdasan emosional empat kali lebih penting dibandingkan dengan kecerdasan kognitif dalam menentukan kesuksesan profesional. Penelitian mengenai prestasi akademik dengan job performance sangat terbatas, dan memiliki hasil yang berbeda. Sepanjang pengetahuan peneliti, setelah melakukan serangkaian pencarian melalui google scholar (https://scholar.google.co.id/) dengan kata kunci kecerdasan emosional, prestasi akademik, job performance, organisasi kemahasiswaan dalam Bahasa Inggris dan bahasa indonesia. Belum ada penelitian mengenai kaitan antara kecerdasan emosional, prestasi akademik dan job performance, yang dilakukan terhadap anggota organisasi kemahasiswaan. Oleh karena itu, peneliti ingin meneliti apakah terdapat hubungan antara kecerdasan emosi, prestasi akademik dengan job perfomance para mahasiswa yang terlibat di dalam organisasi kemahasiswaan.

\section{Kerangka berpikir}

Para mahasiswa yang terlibat di dalam organisasi kemahasiswaan, diharapkan adalah mahasiswa yang berkualitas yang dapat bekerja dan berkarya secara maksimal sehingga memperoleh job performance yang maksimal. Dalam mencapai job perfomance dibutuhkan sumber daya manusia yang berkualitas. Sumber daya manusia yang berkualitas adalah individu yang memiliki kecerdasan intelektual, kecerdasan emosional. Kecerdasan intelektual dilihat melalui indeks prestasi kemahasiswaan. Mahasiswa yang memiliki prestasi akademik yang tinggi, maka akan memiliki ilmu pengetahuan, dan kemampuan dalam pemahaman, penerapan, daya analisis, sintesis, dan evaluasi. Dengan kemampuan tersebut, peneliti berasumsi bahwa mahasiswa mampu menghasilkan banyak ide serta menganalisis kelebihan dan kekurangan dari suatu program kerja. Prestasi akademik merupakan salah satu cara dalam menentukan job performance (Dyer, 1987; Lee, 1988). Selain dari prestasi akademik, kecerdasan emosional juga dianggap penting untuk dimiliki para mahasiswa agar dapat mencapai job performance yang maksimal.

Kecerdasan emosional adalah kemampuan menerapkan daya dan kepekaan emosi. Dalam beroganisasi diperlukan kecerdasan emosional untuk melihat dan memahami emosi sesama anggota organisasi sehingga mampu mencegah masalah ataupun menyelesaikan suatu masalah. Kecerdasan emosional memiliki pengaruh yang besar dalam memiliki karir yang sukses dan job 
performance karena individu yang cerdas emosinya lebih dapat bekerja dengan baik di tempat kerja. Hal ini dikarenakan mereka mampu menjalin hubungan interpersonal, mudah bergaul, lebih bersemangat dalam aktivitas yang berhubungan dengan banyak orang. Sebaliknya orang yang lemah emosinya akan menghadapi masalah dalam berhubungan dengan orang banyak, sulit menyesuaikan diri dan kurang bersemangat dalam mencapai tujuan pekerjaan (Iskandar, Ambarita \& Sowiyah, 2014)

Sebuah organisasi kemahasiswaan dapat berjalan dengan baik ketika anggota dapat bekerja sama dan berkomunikasi dengan baik. Sedangkan dengan memiliki prestasi akademik, para mahasiswa akan mampu menerapkan ilmu pengetahuan, pemahaman, penerapan, daya analisis, sintesis, dan evaluasi dalam menyelesaikan setiap tugasnya dan mencapai job performance yang baik. Oleh karena itu, peneliti berpendapat bahwa memiliki kecerdasan emosional dan prestasi akademik merupakan hal penting untuk mencapai job performance di organisasi kemahasiswaan

\section{Rumusan Masalah}

Rumusan masalah pada penelitian ini adalah apakah terdapat hubungan antara kecerdasan emosional dan prestasi akademik dengan job performance mahasiswa yang terlibat dalam organisasi kemahasiswaan? Jika diuraikan lebih lanjut, maka terdapat tiga pertanyaan:

1. Apakah terdapat hubungan antara kecerdasan emosional dengan job performance?

2. Apakah terdapat hubungan prestasi akademik dengan job performance?

3. Apakah terdapat hubungan antara kecerdasan emosional dengan job performance?

\section{METODE PENELITIAN}

\section{Karakteristik penelitian}

Partisipan yang digunakan dalam penelitian ini adalah mahasiswa yang terlibat dalam organisasi kemahasiswaan yaitu Dewan Perwakilan Mahasiswa (DPM) dan Badan Eksekutif Mahasiswa (BEM) dari setiap Fakultas di Univeristas X. Fakultas tersebut adalah Fakultas Ekonomi, Fakultas Hukum, Fakultas Kedokteran, Fakultas Psikologi, Fakultas Teknologi Informasi, Fakultas Seni Rupa dan Desain, Fakultas Teknik dan Fakultas Ilmu Komunikasi Universitas X.

Pemilihan partisipan tidak dibatasi oleh agama, ras, suku, etnis atau budaya tertentu. Jumlah partisipan dalam penelitian ini adalah 284 orang, yang terdiri dari 121 mahasiwa yang terlibat di DPM dan 163 mahasiswa yang terlibat di BEM. Metode pengambilan sampel dilakukan dengan metode penelitian kuantitatif. Pada awalnya peneliti ingin menggunakan teknik non-probality samplying yaitu stratified sampling. Akibat keterbatasan waktu dalam pengumpulan partisipan, peneliti memutuskan untuk menggunakan cluster sampling sesuai dengan karakteristik partisipan.

\section{Peralatan Penelitian}

Dalam penelitian ini, peneliti telah mempersiapkan kertas kuesioner, informed consent, alat tulis selama proses pengumpulan data. Informed consent akan diperoleh setelah menanyakan kepada setiap partisipan terlebih dahulu apakah mereka bersedia menjadi partisipan penelitian dan meminta mereka mengisi di bagian awal kuesioner agar dapat menunjukkan bahawa partisipan bersedia untuk berpartisipasi.

Peralatan yang digunakan dalam penelitian ini adalah kuesioner yang terdiri dari butir-butir pernyatan yang diisi dengan skala interval likert. Kuesioner ini akan digunakan untuk 
mengidentifikasi hubungan antara kecerdasan emosional dan prestasi akademik dengan job performance pada mahasiswa yang terlibat dalam organisasi kemahasiswaan. Kuesioner kecerdasan emosional terdiri dari 60 butir dengan jumlah butir positif sebanyak 30 butir dan butir negatif sebanyak 30 butir. Sedangkan kuesioner job performance terdiri dari 3 bagian, yaitu kuesioner yang diisi diri sendiri, kuesioner yang menilai orang lain dan kuesioner yang dinilai oleh ketua. dimana setiap bagiannya terdiri dari 6 butir. Kuesioner prestasi akademik digabungkan dengan bagian identitas diri partisipan.

Kuesioner yang digunakan terdiri 12 bagian. Pada lembar awal kuesioner terdapat informasi penelitian yang dilakukan peneliti dan inform consent yang digunakan untuk menunjukkan bahwa partisipan bersedia untuk berpartisipasi penelitian. Setelah lembar informed consent, lembar berikutnya adalah data diri partisipan sebagai data pelengkapan dalam penelitian ini. Lembar berikutnya adalah data diri pengalaman organisasi yang pernah diikuti oleh partisipan.

Lembar berikutnya adalah petunjuk pengisian kuesioner job performace satu dengan satu contoh butir di dalamnya. Kemudian lembar berikutnya berisi 6 butir kuesioner. Lembar berikutnya adalah petunjuk pengisian kuesioner job performace dua dengan satu contoh butir di dalamnya. Kemudian lembar berikutnya berisi 6 butir kuesioner. Lembar berikutnya adalah petunjuk pengisian kuesioner job performace tiga dengan satu contoh butir di dalamnya. Kemudian lembar berikutnya berisi 6 butir kuesioner. Lembar berikutnya adalah petunjuk pengisian kuesioner kecerdasan emosional dengan satu contoh butir di dalamnya. Kemudian lembar berikutnya berisi butir-butir kuesioner. Instrumen lain dalam penelitian ini adalah hadiah. Hadiah digunakan sebagai ucapan terima kasih peneliti pada partisipan karena telah berpartisipasi dalam penelitian.

\section{Pengukuran Penelitian}

\section{Pengukuran Variabel Kecerdasan Emosional}

Definisi operasional dari kecerdasan emosional adalah kemampuan merasakan, memahami, dan dengan efektif menerapkan daya dan kepekaan emosi sebagai sumber energi, informasi, dan pengaruh yang manusiawi (Goleman,1998). Semakin tinggi tingkat kecerdasan emosi, maka tingkat job performance semakin baik hasil job performance para mahasiswa. Sedangkan semakin rendah sekor dari kuesioner kecerdasan emosi, maka kurang baik job performance dicapai oleh anggota organisasi kemahasiswaan. Kuesioner kecerdasan emosional terdiri dari 60 butir. Responden akan diberikan pertanyaan seperti ketika saya marah, maka saya tahu penyebab kemarahan saya. Jawaban responden antara lain STS: sangat tidak setuju, TS: tidak setuju, RR: ragu-ragu, S: Setuju, SS: sangat setuju. 
Tabel 1. Dimensi alat ukur kecerdasan emosional

\begin{tabular}{|c|c|}
\hline Dimensi & Indikator \\
\hline self-awareness & $\begin{array}{l}\text { - Mengetahui alasan dari perasaan yang saya } \\
\text { rasakan. } \\
\text { - Mengetahui rencana saya ke depan. } \\
\text { - Mampu mengambil keputusan } \\
\text { - Mengetahui apa yang saya rasakan. }\end{array}$ \\
\hline managing emotions & $\begin{array}{l}\text { - Mampu mengerjakan tanggung jawab saat } \\
\text { emosi } \\
\text { - Mampu mengendalikan emosi saya secara } \\
\text { tepat. } \\
\text { - Mampu mengatur keinginan serta emosi }\end{array}$ \\
\hline motivating other & $\begin{array}{l}\text { - Memiliki tujuan yang ingin dicapai } \\
\text { - Mampu berpikir positif } \\
\text { - Memiliki motivasi untuk membantu orang lain }\end{array}$ \\
\hline empathy skills & $\begin{array}{l}\text { - Mampu merasakan apa yang dirasakan orang } \\
\text { - Main. } \\
\text { - Mau membantu dan peduli pada orang lain. } \\
\text { - Mengetahui perasaan orang lain. }\end{array}$ \\
\hline handling relationship & $\begin{array}{l}\text { - Mampu menjalin hubungan dengan orang lain. } \\
\text { - Senang terlibat di dalam suatu kelompok. } \\
\text { - Mudah bergaul dengan orang lain. }\end{array}$ \\
\hline
\end{tabular}

Melalui hasil uji reliabilitas diketahui bahwa koefisien alpha cronbach alat ukur kecerdasan emosional dimensi self awareness $(\alpha=0,65)$, dimensi managing emotions $(\alpha=0,74)$, dimensi motivating other $(\alpha=0,76)$, dimensi empathy skill $(\alpha=0,80)$, dan dimensi handling relationship $(\alpha=0,812)$. Untuk hasil uji reliabiltas dan dapat dilihat pada tabel 2 .

Tabel 2. Uji Reliabilitas dan Kuesioner Kecerdasan Emosional

\begin{tabular}{ccc}
\hline Dimensi & Sebelum & Sesudah \\
\hline Self Awareness & 0,46 & 0,65 \\
Managing Emotions & 0,64 & 0,74 \\
Motivating Other & 0,68 & 0,76 \\
Empathy Skill & 0,49 & 0,80 \\
Handling Relationship & 0,80 & 0,82 \\
\hline
\end{tabular}

\section{Pengukuran Variabel IPK Terakhir}

Definisi operasional dari prestasi akademik adalah penilaian hasil pendidikan untuk mengetahui pada waktu dilakukannya penilaian sejauh manakah anak didik setelah ia belajar dan berlatih dengan sengaja (Chaplin, 2008). Dimana prestasi akademik mahasiswa akan dilihat berdasarkan indeks pretasi kumulatif (IPK).

\section{Pengukuran Variabel Job Performance}

Definisi operasional dari job performance adalah hasil kerja yang efektif dari pelaksanaan tugas anggota organisasi kemahasiswaan sesuai dengan job description dalam AD/ART \& program 
kerja, yang diukur melalui kuesioner Job performance dalam organisasi kemahasiswaan. Menurut Sonnentag dan Frese (2002), job performance adalah sebuah dimensi yang mengindikasikan seberapa baik mereka mengerjakan tugasnya, seberapa inisiatif yang mereka miliki dan bagaimana usaha mereka dalam menyelesaikan masalah. Maka semakin tinggi, skor dari kuesioner ini makin baik hasil kerja yang dicapai oleh anggota organisasi kemahasiswaan. Sedangkan semakin rendah sekor dari kuesioner ini, makin kurang baik hasil kerja yang dicapai oleh anggota organisasi kemahasiswaan.

Kuesioner job performance diadaptasi dari Sonnentag dan Frese (2002). Pada kuesioner ini akan diberikan pada tiga penilaian yaitu, dari diri sendiri, rekan kerja dan ketua. Oleh karena itu, setiap kuesioner akan memiliki 2 butir pernyataan mengenai dimensi task performance, dimensi adaptive performance dan dimensi contextual performance. Reliabitas job performance dapat dilihat pada tabel 3. Setiap dimensi memiliki total 6 butir untuk setiap dimensinya. Reliabilitas alat ukur dimensi task performance kuesioner diri sendiri $(\alpha=0,52)$, rekan kerja $(\alpha=0,76)$, dan ketua $(\alpha=0,79)$. Selanjutnya, reliabilitas alat ukur dimensi adaptive performance kuesioner diri sendiri $(\alpha=0,61)$, rekan kerja $(\alpha=0,66)$, dan ketua $(\alpha=0,55)$. Reliabilitas alat ukur dimensi contextual performance kuesioner diri sendiri $(\alpha=0,63)$ rekan kerja $(\alpha=0,74)$ ketua $(\alpha=0,54)$. Untuk lebih jelas dapat dilihat pada dan tabel 3.

Tabel 3. Uji Reliabilitas Job performance

\begin{tabular}{clc}
\hline \multicolumn{1}{c}{ Dimensi } & & Alpha cronbach \\
\hline task performance & ditinjau dari diri sendiri & 0,52 \\
& ditinjau dari rekan kerja & 0,76 \\
& ditinjau dari ketua & 0,79 \\
adaptive performance & ditinjau dari diri sendiri & 0,61 \\
& ditinjau dari rekan kerja & 0,66 \\
contextual performance & ditinjau dari ketua & 0,55 \\
& ditinjau dari diri sendiri & 0,63 \\
& ditinjau dari rekan kerja & 0,74 \\
& ditinjau dari ketua & 0,54 \\
\hline
\end{tabular}

\section{Persiapan Penelitian}

Persiapan penelitian ini dilakukan dengan mencari fenomena yang ada di masyarakat. Setelah menemukan fenomena di masyarakat, hal berikutnya yang harus dipersiapkan adalah alat ukur. Pada penelitian ini ada tiga alat ukur yang harus dipersiapkan yaitu alat ukur kecerdasan emosional, alat ukur job performance, dan alat ukur prestasi akademik. Persiapan berikutnya adalah peneliti menghubungi setiap ketua organisasi kemahasiswaan yang ingin dilibatkan untuk menjelaskan dan meminta ijin untuk menyebar kuesioner. Selain itu, peneliti harus mempersiapkan informed consent serta hadiah sebagai ucapan tanda terima kasih.

\section{Pelaksanaan Penelitian}

Pelaksanaan penelitian ini dimulai dengan pembagian kuesioner ke stiap organisasi kemahasiswaan. Peneliti yang terlebih dulu meminta ijin kepada setiap ketua organisasi kemahasiswaan (DPM dan BEM). Peneliti membuat janji dengan ketua organisasi tersebut untuk menjelaskan mengenai kuesioner penelitian yang disebarkan. Peneliti memulainya dari bagian paling depan yang berisi informasi penelitian berserta informed consent. Yang kemudian 
dilanjutkan dengan bagian identitas partisipan dan pengalaman organisasi partisipan. Selanjutnya peneliti menjelaskan bagaimana cara pengerjaan kuesioner sesuai dengan contoh soal yang telah diberikan. Pada akhirnya, kuesioner yang telah disiapkan akan dititipkan kepada ketua agar diisi oleh para anggota organisasi kemahasiswaan.

\section{Pengolahan dan Teknik Analisis Data}

Data yang telah diterima akan di input ke dalam program. Hal pertama yang dilakukan adalah menguji reliabitias dan butir. Kemudian, peneliti akan menguji normalitas dari butir untuk menentukan uji korelasi yang akan digunakan. Pada analisis data utama, analisis yang dilakukan adalah untuk mengetahui apakah terdapat hubungan antara kecerdasan emosional dan prestasi akademik dengan job performance. Untuk mengetahui hasil tersebut harus menggunakan uji korelasi. Sebelumnya peneliti harus memperhatikan hasil uji normalitas dari ketiga variabel. Pada uji normalitas pada ketiga variabel ditemukan bahwa data terdistribusi tidak normal. Oleh karena itu, uji korelasi yang digunakan adalah uji korelasi spearman.

Pada analisis data tambahan, peneliti ingin meneliti hubungan dari kelima dimensi kecerdasan emosional, prestasi akademik dan tiga dimensi job performance. Untuk meneliti hal tersebut, peneliti harus menggunakan teknik analisis yang sama yaitu uji korelasi spearman. Selain itu, peneliti juga ingin meneliti mengenai perbedaan dari organisasi kemahasiswaan DPM dan BEM. Variabel yang ingin diuji adalah kecerdasan emosional, prestasi akademik dan job performance. Uji beda yang dilakukan adalah uji beda Mann-Whitney, hal tersebut dikarenakan terdapat dua kelompok yang di uji.

\section{HASIL DAN PEMBAHASAN}

Berdasarkan hasil uji korelasi menggunakan teknik sperman correlation diperoleh hasil bahwa prestasi akademik memiliki hubungan yang signifikan dengan job performance ditinjau oleh ketua $(r=0,147, p=0<0,05)$. Hasil korelasi juga menunjukkan kecerdasan emosional memiliki hubungan signifikan dengan job performance ditinjau oleh diri sendiri, dengan $(r=0,338, p=0$ $<0,01)$. Untuk lebih jelasnya dapat dilihat pada tabel 4 .

Tabel 4 . Hasil Uji Korelasi Variabel Kecerdasan emosional, Prestasi Akademik dan Job performance $(\mathrm{N}=284)$

\begin{tabular}{|c|c|c|c|c|}
\hline & $\begin{array}{c}\text { Prestasi } \\
\text { Akademik }\end{array}$ & $\begin{array}{c}\text { Ditinjau dari Diri } \\
\text { Sendiri }\end{array}$ & $\begin{array}{c}\text { Job Performance } \\
\text { Ditinjau dari Rekan } \\
\text { Kerja }\end{array}$ & $\begin{array}{c}\text { Ditinjau dari } \\
\text { Ketua }\end{array}$ \\
\hline Kecerdasan & $r=-0,013$ & $r=0,34 ; p<0,05$ & $r=0,08 ; p>0,05$ & $r=-0,108 ; p>0,05$ \\
\hline Emosional & $\begin{array}{l}p>0,05 \\
\text { Tidak ada } \\
\text { hubungan }\end{array}$ & $\begin{array}{l}\text { Terdapat } \\
\text { hubungan }\end{array}$ & $\begin{array}{l}\text { Tidak ada } \\
\text { hubungan }\end{array}$ & $\begin{array}{l}\text { Tidak ada } \\
\text { hubungan }\end{array}$ \\
\hline Prestasi & & $r=-, 01 ; p>0,05$ & $r=0,06 ; p>0,05$ & $r=0,15 ; p<0,05$ \\
\hline Akademik & & $\begin{array}{l}\text { Tidak ada } \\
\text { hubungan }\end{array}$ & $\begin{array}{l}\text { Tidak ada } \\
\text { hubungan }\end{array}$ & $\begin{array}{r}\text { Terdapat } \\
\text { hubungan }\end{array}$ \\
\hline
\end{tabular}

Hasil ini menunjukkan pertama, terdapat hubungan antara kecerdasan emosional dan job performance pada mahasiswa yang terlibat di organisasi kemahasiswaan yang ditinjau dari diri sendiri $(r=0,34 ; p<0,05)$ tetapi tidak ada hubungan antara kecerdasan emosional dengan job performance pada mahasiswa yang terlibat di organisasi kemahasiswaan yang ditinjau dari rekan kerja $(r=0,08 ; p>0,05)$ dan ketua $(r=-0,108 ; p>0,05)$. 
Kedua, terdapat hubungan antara prestasi akademik dengan job performance pada mahasiswa yang terlibat di organisasi kemahasiswaan yang ditinjau dari ketua $(r=0,15 ; p<0,05)$, tetapi tidak ada hubungan antara kecerdasan emosional dengan job performance pada mahasiswa yang terlibat di organisasi kemahasiswaan yang ditinjau dari diri sendiri $(r=-, 01 ; p>0,05)$ dan rekan kerja $(r=0,06 ; p>0,05)$. Ketiga, tidak terdapat hubungan antara kecerdasan emosional dengan prestasi akademik pada mahasiswa yang terlibat di organisasi kemahasiswaan $(r=-0,013$; $p>=0,05)$.

\section{Analisis Data Tambahan}

Peneliti melakukan beberapa analisis data tambahan pada penelitian ini. Peneltian ini memiliki delapan temuan sebagai analisi data tambahan. Pertama, peneliti melakukan uji korelasi menggunakan teknik spearman correlation antara lima dimensi kecerdasan emosional, prestasi akademik dan job performance dimensi task performance menunjukkan bahwa IPK memiliki hubungan signifikan dengan Kecerdasan emosional dimensi handling relationship $(\mathrm{r}=-0,120$ dan nilai $p=0<0,01)$.

Hasil korelasi lainnya adalah terjadi hubungan signifikan antara lima dimensi Kecerdasan emosional dengan job performance dimensi task performance. Pada hasil korelasi dimensi pertama yaitu dimensi nilai self awareness $(r=0,226, p=0>0,05)$. Pada hasil korelasi dimensi kedua yaitu managing emotions, $(r=0,173, \quad p=0>0,05)$. Pada hasil korelasi dimensi ketiga yaitu, motivating other $(r=0,235, p=0>0,05)$. Pada dimensi keempat, yaitu empathy skill ( $r=$ $0,244, p=0>0,05)$. Selain itu, pada dimensi terakhir yaitu, handling relationship $(r=0,239, p=$ $0>0,05$. Untuk lebih jelasnya dapat dilihat pada tabel 5 .

Tabel 5. Hasil Uji Korelasi Lima Dimensi Kecerdasan emosional, Prestasi Akademik dan Job Performance Dimensi Task Performance

\begin{tabular}{|c|c|c|c|}
\hline Variabel & Variabel & $\mathrm{r}$ & $\mathrm{p}$ \\
\hline Prestasi Akademik & $\begin{array}{c}\text { Kecerdasan emosional } \\
\text { Dimensi Handling } \\
\text { Relationship }\end{array}$ & $-0,12$ & 0,44 \\
\hline $\begin{array}{l}\text { Kecerdasan emosional } \\
\text { Dimensi Self Awareness }\end{array}$ & $\begin{array}{c}\text { Job Performance Dimensi } \\
\text { Task Performance }\end{array}$ & 0,23 & 0,00 \\
\hline $\begin{array}{c}\text { Kecerdasan emosional } \\
\text { Dimensi Managing } \\
\text { Emotions }\end{array}$ & $\begin{array}{c}\text { Job Performance Dimensi } \\
\text { Task Performance }\end{array}$ & 0,17 & 0,003 \\
\hline $\begin{array}{c}\text { Kecerdasan emosional } \\
\text { Dimensi Motivating Other }\end{array}$ & $\begin{array}{c}\text { Job Performance Dimensi } \\
\text { Task Performance }\end{array}$ & 0,24 & 0,00 \\
\hline $\begin{array}{l}\text { Kecerdasan emosional } \\
\text { Dimensi Empathy Skill }\end{array}$ & $\begin{array}{c}\text { Job Performance Dimensi } \\
\text { Task Performance }\end{array}$ & 0,24 & 0,00 \\
\hline $\begin{array}{c}\text { Kecerdasan emosional } \\
\text { Dimensi Handling } \\
\text { Relationship }\end{array}$ & $\begin{array}{c}\text { Job Performance Dimensi } \\
\text { Task Performance }\end{array}$ & 0,24 & 0,00 \\
\hline
\end{tabular}

Kedua, peneliti melakukan uji korelasi menggunakan teknik sperman correlation antara lima dimensi kecerdasan emosional, prestasi akademik dan job performance dimensi adaptive performance menunjukkan bahwa tidak ada hubungan signifikan antara lima dimensi Kecerdasan emosional, prestasi akademik dan job performance dimensi adaptive performance. 
Ketiga, peneliti pun memperoleh hasil bahwa terdapat hubungan antara prestasi akademik dengan job performance dimensi contextual performance dengan $(\mathrm{z}=0,14, p>0,05)$. Keempat, peneliti melakukan uji beda Mann-Whitney terhadap tingkat kecerdasan emosional antara mahasiswa yang terlibat di DPM dan BEM $(z=0,58, p>0,5)$. Dengan demikian, tidak ada perbedaan signifikan dari kecerdasan emosional antara mahasiswa yang terlibat di DPM dan BEM. Untuk lebih jelas dapat dilihat pada tabel 6. Kelima, peneliti juga melakukan uji beda Mann-Whitney terhadap prestasi akademik antara mahasiswa yang terlibat di DPM dan BEM ( z $=0,61 ; p>0,5)$. Dengan demikian, tidak ada perbedaan signifikan dari prestasi akademik antara mahasiswa yang terlibat di DPM dan BEM.

Keenam, peneliti juga melakukan uji beda Mann-Whitney terhadap job performance dimensi task performance antara mahasiswa yang terlibat di DPM dan BEM ( $\mathrm{z}=0,78 ; p>0,5)$. Dengan demikian, tidak ada perbedaan signifikan dari job performance dimensi task performance antara mahasiswa yang terlibat di DPM dan BEM. Ketujuh, peneliti juga melakukan uji beda MannWhitney terhadap job performance dimensi adaptive performance antara mahasiswa yang terlibat di DPM dan BEM ( $\mathrm{z}=0,38, p<0,5)$. Dengan demikian, terdapat perbedaan signifikan dari job performance dimensi adaptive performance antara mahasiswa yang terlibat di DPM dan BEM.

Kemudian, peneliti juga melakukan uji beda Mann-Whitney terhadap job performance dimensi contextual performance antara mahasiswa yang terlibat di DPM dan BEM ( $\mathrm{z}=0,10, p<0,5)$. Dengan demikian, terdapat perbedaan signifikan dari job performance dimensi contextual performance antara mahasiswa yang terlibat di DPM dan BEM.

Tabel 6. Uji Perbedaan Kecerdasan Emosional, Prestasi Akademik dan Tiga Dimensi Job performance Dengan Organisasi Kemahasiswaan DPM dan BEM

\begin{tabular}{|c|c|c|c|c|}
\hline Variabel & $\begin{array}{l}\text { Mean } \\
\text { DPM }\end{array}$ & $\begin{array}{l}\text { Mean } \\
\text { BEM }\end{array}$ & $\mathrm{Z}$ & $p$ \\
\hline Kecerdasan Emosional & 139,37 & 144,38 & $-0,55$ & 0,58 \\
\hline Prestasi Akademik & 145,40 & 140,34 & $-0,51$ & 0,61 \\
\hline $\begin{array}{l}\text { Job performance dimensi task } \\
\text { performance }\end{array}$ & 140,92 & 143,67 & $-0,28$ & 0,78 \\
\hline $\begin{array}{l}\text { Job performance dimensi adaptive } \\
\text { performance }\end{array}$ & 137,56 & 146,17 & $-0,88$ & 0,38 \\
\hline $\begin{array}{l}\text { Job performance dimensi contextual } \\
\text { performance }\end{array}$ & 151,13 & 135,18 & $-1,63$ & 0,10 \\
\hline
\end{tabular}

\section{KESIMPULAN DAN SARAN}

\section{Kesimpulan}

Hasil dari penelitian ini menunjukkan bahwa pertama terdapat hubungan antara kecerdasan emosional dengan job performance ditinjau dari diri sendiri, tetapi tidak terdapat hubungan dengan job performance ditinjau dari rekan kerja dan ketua. Kedua, terdapat hubungan antara prestasi akademik dengan job performance ditinjau dari ketua tetapi tidak ada hubungan dengan job performance ditinjau dari diri sendiri dan rekan kerja. Ketiga, tidak ada hubungan antara kecerdasan emosional dengan prestasi akademik. 


\section{Diskusi}

Hasil dari penelitian ini menunjukkan pertama, terdapat hubungan antara kecerdasan emosional dengan job performance yang ditinjau dari diri sendiri. Kecerdasan emosional memiliki hubungan yang positif terhadap job performance (Iskandar, Ambarita dan Sowiyah, 2014; Sy, Tram, \& O'Hara, 2006). Hal ini dikarenakan mereka mampu menjalin hubungan interpersonal, mudah bergaul, lebih bersemangat dalam aktivitas yang berhubungan dengan banyak orang sehingga membantu dalam mencapai job performance. Dikatakan juga bahwa kecerdasan emosional memiliki hubungan dalam motivasi kerja yang mendukung job performance. Para mahasiswa yang memiliki kecerdasan emosional yang baik akan memiliki hubungan yang baik dengan anggota yang lain sehingga dapat melakukan job performance yang baik. Kecerdasan emosional itu sendiri dipercaya sebagai salah satu faktor penting yang mempengaruhi job performance dibandingkan dengan kemampuan kognitif seseorang (Nowack, 2011). Menurut Chien Farh, Seo dan Tesluk (2012), kecerdasan emosional meningkatkan job performance dalam hal keefektifan kerja sama team dalam konten kerja manajemen sehingga menyebabkan individu dengan kecerdasan emosi yang tinggi untuk bertindak secara cerdas emosinya untuk mendukung kinerja mereka

Kedua, tidak terdapat hubungan antara kecerdasan emosi dan job performance ditinjau dari rekan kerja. Ketiga, tidak terdapat hubungan antara kecerdasan emosi dan job performance ditinjau dari ketua. Keempat, terdapat hubungan antara prestasi akademik dengan job performance ditinjau dari ketua. Sebagian besar organisasi kemahasiswaan memiliki syarat, dimana mahasiswa harus memiliki indeks prestasi kumulatif di atas batas minimum yang telah ditetapkan. Prestasi akademik digunakan sebagai salah satu syarat disebabkan sebagai suatu cara untuk mengetahui kemampuan para mahasiswa dalam bidang pengetahuan, pemahaman, penerapan, daya analisis, sintesis, dan evaluasi. Kelima, tidak ada hubungan antara prestasi akademik dengan job performance ditinjau dari diri sendiri dan rekan kerja. Hal ini disebabkan para anggota merasa bahwa prestasi akademik bukanlah hal yang penting karena dengan ada pengalaman merupakan salah satu cara belajar yang paling efektif dalam berorganisasi.

Keenam, tidak ada hubungan antara kecerdasan emosional dengan prestasi akademik. Hasil yang diperoleh berbeda dengan beberapa penelitian yang telah dilakukan sebelum. Pada beberapa penelitian sebelumnya (Shipley, Jackson, \& Segrest, 2010; Maria, 2015; Wati, Yusmansyah \& Widiastuti, 2014), menunjukkan bahwa kecerdasan emosional memiliki hubungan yang signifikan dengan prestasi akademik. Pada penelitian ini memiliki hasil menunjukkan bahwa tidak ada hubungan antara kedua variabel. Menurut Côté \& Miners (2006), kecerdasan emosional dan kecerdasan kognitif dianggap sebagai dua hal yang berbeda namun merupakan bagian dari general intelligence (4).

Pada hasil analisis tambahan mengenai korelasi lima dimensi kecerdasan emosional, prestasi akademik dan tiga dimensi job performance diperoleh hasil bahwa terdapat hubungan signifikan antara lima dimensi kecerdasan emosional dengan job performance dimensi task performance. Dari penelitian menyatakan bahwa kecerdasan emosional memiliki pengaruh yang besar dalam peran memiliki karir yang sukses dan job performance dibandingkan kemampuan kognitif. Bisa dikatakan pula melalui penelitian, bahwa kecerdasan emosional berkorelasi dengan job performance (Van Rooy \& Viswesvaran, 2004).

Pada analisis data tambahan berikutnya, peneliti melakukan uji beda kecerdasan emosional pada anggota organisasi kemahasiswaan DPM dan BEM. Hasilnya menunjukkan bahwa tidak ada 
perbedaan yang siginifikan pada kecerdasan emosional. Selanjutnya, peneliti melakukan uji beda pada job performance dimensi task performance. Hasilnya menunjukkan tidak ada perbedaan yang signifikan diantara para anggota organisasi kemahasiswaan DPM dan BEM. Kemudian, pada uji beda job performance dimensi adaptive performance, memiliki hasil yang berbeda. Hasilnya menunjukkan bahwa terdapat perbedaan yang cukup signifikan di antara para anggota organisasi kemahasiswaan DPM dan BEM. Pada hasil uji beda ini, anggota organisasi kemahasiswaan BEM memiliki hasil yang lebih tinggi dibandingkan dengan anggota organisasi kemahasiswaan DPM. Hasil tersebut sesuai dengan tugas organisasi kemahasiswaan BEM, yang melakukan eksekusi dari aspirasi mahasiswa yang ditampung oleh DPM. BEM harus mampu menyediakan berbagai wadah aktifitas yang kreatif dan terus berubah sesuai dengan bakat minat para mahasiswa. Oleh karena itu, adaptive performance pada BEM cenderung lebih baik dibandingkan dengan DPM.

Pada uji beda job performance dimensi contextual performance diperoleh hasil bahwa terdapat perbedaan yang signifikan diantara para anggota organisasi kemahasiswaan DPM dan BEM. Anggota organisasi kemahasiswaan DPM memiliki hasil yang lebih tinggi pada contextual performance dibandingkan dengan anggota organisasi kemahasiswaan BEM. Hal ini dapat terlihat dari tugas DPM, sebagai lembaga legislatif yaitu menampung aspirasi mahasiswa, pengawasan, advokasi, budgeting pada BEM. Sehingga para anggota DPM memiliki peranan secara langsung dan tidak langsung pada perkembangan BEM, seperti definisi contextual performance.

\section{Saran yang Berkaitan dengan Manfaat Teoritis}

Saran yang terkait dengan manfaat teoritis adalah adanya tambahan kajian literatur mengenai kecerdasan emosional, prestasi akademik dan job performance. Kajian literatur mengenai kecerdasan emosional banyak diadaptasi oleh buku internasional, namun jumlah penelitian kecerdasan emosional cukup sedikit di Indonesia. Hal tersebut juga dirasakan dengan prestasi akademik pun memiliki kajian literatur dan jumlah penelitian yang terbatas sedangkan untuk jumlah penelitian mengenai job performance di perusahaan tergolong banyak. Hanya saja untuk penelitian job performance mahasiswa yang terlibat di organisasi kemahasiswaan sangat minim jumlahnya. Saran untuk penelitian berikutnya adalah lebih banyak partisipan dari beragam organisasi kemahasiswaan yang terlibat dalam penelitian sehingga mampu menjadi pembanding dalam tingkat kecerdasan emosional, prestasi akademik dan job performance mahasiswa yang terlibat di organisasi kemahasiswaan.

\section{Saran yang Berkaitan dengan Manfaat Praktis}

Saran yang terkait dengan manfaat praktis adalah penggunaan hasil penelitian ini untuk penelitian selanjutnya khususnya yang berhubungan dengan kecerdasan emosional, prestasi akademik dan job performance mahasiswa yang terlibat di organisasi kemahasiswaan. Sehingga semakin banyak penelitian yang membahas mengenai kecerdasan emosional, prestasi akademik dan job performance mahasiswa yang terlibat di organisasi kemahasiswaan. Melalui hasil penelitian ini, diharapkan Pembantu Dekan bagian Kemahasiswaan atau koordinator bidang kemahasiswaan maupun pihak fakultas menyediakan waktu untuk melakukan tes, terkait kecerdasan emosional dan prestasi akademik melalui kecerdasan kognitif, kepada para mahasiswa yang terlibat di dalam organisasi kemahasiswaan maupun secara umum. Dengan mengetahui tingkat kecerdasan emosional dan kecerdasan kognitif para mahasiswa, Pembantu Dekan atau koordinator kemahasiswaan atau pihak fakultas mampu mengembangkan dan meningkatkan kemampuan para mahasiswa. 


\section{REFERENSI}

Agustian, A.G. (2001). Rahasia sukses membangun kecerdasan emosi dan spiritual ESQ. Jakarta: Arga.

Chaplin, J.P. (2008). Kamus Psikologi Lengkap. Jakarta: PT Raja Grafindo.

Chi, H. K., Tsai, H. P., \& Chang, P. F. (2007). Investigating the relationship among leadership styles, emotional intelligence and organized commitment on job performance: A study of salespeople in Thailand. The Journal of Human Resource an Adult Learning. 3(2). 199212.

Chien Farh, C.I.C., Seo, M.G., \& Tesluk, P. E. (2012), Emotional intelligence, teamwork effectiveness, and job performance: The moderating role of job context. Journal of Applied Psychology. 97 (4). 890-900.

Côté, S., \& Miners, C. T. H. (2006). Emotional Intelligence, Cognitive Intelligence, and Job Performance. Administrative Science Quarterly, 51(1), 1-28.

Dyer, E. D. (1987). Can university success and first-year job performance be predicted from academic achievement, vocational interest, personality and biographical measures? Psychological Reports, 61(2), 655-671. doi:10.2466/pr0.1987.61.2.655

Goleman, D. (1998). Working with emotional intelligence. New York: Bantam Books

Ikatan Besar Mahasiswa Tarumanagara. (2014). Keputusan Majelis Permusyawaratan mahasiswa Universitas Tarumanagara Nomor: 001 Tahun 2014 tentang petunjuk pelaksanaan struktur organisasi mahasiswa di Universitas Tarumanagara. Jakarta.

Iskandar, D. Ambarita, A., \& Sowiyah, S. (2014) Pengaruh kecerdasan emosional dan motivasi berprestasi terhadap kinerja guru. Jurnal Manajemen Mutu Pendidikan 2(3)

Keputusan Menteri Pendidikan dan Kebudayaan Republik Indonesia NOMOR 155/U/1998. (1998). Pedoman umum organisasi kemahasiswaan di perguruan tinggi Menteri Pendidikan dan Kebudayaan.

Lee, D. M. S. (1988). Academic achievement, task characteristics, and first job performance of young engineers. In R. Katz (Ed.), Managing professionals in innovative organizations: A collection of readings (pp. 49-61). New York: Ballinger/Harper \& Row. (Reprinted from "IEEE Transactions on Engineering Management," Vol. EM-33, No. 3, pp. 127-133, August 1986)

Maria, M. (2015). Kecerdasan emosional dan pencapaian prestasi akademik mahasiswa di jurusan akuntansi politeknik negeri sriwijaya. Jurnal Wahana Ekonomika.

Nowack, K. (2011). Leadership, emotional intelligence and employee engagement: Creating a psychology healthy workplace. Envisia Learning.

Rothmann, S. \& Coetzser, E.P. (2003). The big five personality dimensions and job performance. Journal of industrial psychology, 29(1), 68-74.

Shipley, N.L., Jackson, M.J. \& Segrest.S.L. (2010). The effects of emotional intelligence, age, work experience, and academic performance. Research in Highest Education Journal.

Sonnentag, S. \& Frese, M. (2002). Performance concepts and performance theory. Psychological management of individual performance.

Suryabrata, S. (1998) Psikologi pendidikan. Jakarta : PT. Raja Grafindo Persada.

Sy, T., Tram, S., \& O'Hara, L. A. (2006). Relation of employee and manager emotional intelligence to job satisfaction and performance. Journal of Vocational Behavior, 68(3), 461-473. doi:10.1016/j.jvb.2005.10.003

Tangkilisan, H.N.S. (2007). Manajemen publik. Jakarta : PT. Grasindo 
Van Rooy, D.L. \& Viswesvaran, C. (2004). Emotional intelligence: A meta-analytic investigation of predictive validity and nomological net. Journal of Vocational Behavior, 65(1),71-95.

Yazidulfalach, A. (2012). Dampak kesertaan mahasiswa pada lembaga kemahasiswaan terhadap prestasi akademik (studi kasus mahasiswa jurusan akuntansi S1 Fakultas ekonomi dan bisnis Universitas Brawijaya). Jurnal Ilmiah mahasiswa, 2(1).

Wati,L.E., Yusmansyah,Y., \& Widiastuti,R. (2014). Hubungan antara kecerdasan emosional dengan prestasi belajar. Jurnal ALBKIN.(.3( 3). 